The Geographical Journal of Nepal

Vol. 11: 95-112, 2018

Central Department of Geography,

Tribhuvan University, Kathmandu, Nepal

\title{
Causes and consequences of fragmentation of agricul- tural land: A case of Nawalparasi district, Nepal
}

\author{
Bhola Nath Dhakal ${ }^{1 *}$; and Narendra Raj Khanal ${ }^{2}$ \\ ${ }^{I}$ Ratna Rajyalaxmi Campus, Tribhuvan University,, Bhrikuti Mandap, Kathmandu, \\ Nepal; ${ }^{2}$ Central Department of Geography, Tribhuvan University, Kathmandu, Nepal \\ ("Corresponding Author: dhakalbn@gmail.com)
}

This paper discusses the causes and consequences of agricultural land fragmentation in Nawalparasi district. Primary and secondary sources of information at District and Village Development Committees (Now Municipalities and Rural Municipalities) levels are used. A total of 93 households were interviewed in three VDCs from Nawalparasi district of Nepal. Socio-economic, legal and infrastructure development factors are responsible for fragmentation of agricultural land. Results showed that there has been decreasing productivity of land due to fragmentation of agricultural land. It is mainly due to increasing time of labor input, less opportunity of using modern chemical fertilizer on the one hand and the problem in using modern agricultural equipment such as tractors on the other.

Keywords: Agriculture; land fragmentation; causes; implication; development; Nawalparasi district; Nepal.

\section{Introduction}

Land is the important resource for food, shelter and clothes. Land is an essential natural resource, both for the survival and prosperity of humanity and for the maintenance of all global ecosystems (FAO, 2008). It is a basic resource for agricultural production. People use land for agricultural purposes in parcels distributed in different areas. Such type of practices is called land fragmentation. Land fragmentation is a phenomenon which exists when a household operates a number of owned or rented non-contiguous plots at the same time (Wu et al., 2005). Land fragmentation can be defined as a situation where a farming household possesses several non-contiguous land plots, often scattered over a wide area (Bentley, 1987). When a number of non-contiguous owned or leased farms 
(or 'plots') of land are farmed as a single production unit, land fragmentation exists (McPherson,1982). Land fragmentation is the division of land into a great number of distinct plots (Dovring \& Dovring, 1960). It is also a process of decreasing in the average size of farm holdings; increasing in the scattering of each farmer's land; and decreasing in the size of the individual plots in a farm holding (Agarwal, 1972). Land fragmentation has been a prominent feature in many countries since at least the 17th century (Shuhao, 2005). On the basis of ownership, use and location, four types of land fragmentation are commonly reported: i) ownership fragmentation which refers to the number of landowners who use a given piece of land, ii) land user's fragmentation which refers to the number of users that are also tenants of the land, iii) internal fragmentation (within a farm) which refers to the number of parcels exploited by each user and considers parcel size, shape and distance as the main issues, and iv) separation of ownership and use; which involves the situation where there is a discrepancy between ownership and use (Van Dijk, 2003).The existence of fragmented land holdings is regarded as an important feature of less developed agricultural systems. The main factors triggering land fragmentation are inheritance; population growth; land markets; and historical/ cultural background (Niroula and Thapa, 2005; Tan et al., 2006; Van et al., 2007). According to Shuhao (2005) and Jha et al., (2005), land fragmentation leads to increased travelling time between fields, hence the impact is the lower labour productivity and higher transport cost for inputs and outputs. They noted that fragmentation also involves negative externalities such as reduced scope for irrigation, soil conservation investments and loss of land for boundaries and access routes. Rahman and Rahman (2008) reported that land fragmentation has a significant detrimental effect on productivity and efficiency. Land fragmentation is a common feature of agriculture in many developing countries and leading to inefficient farm management (Sundquist, 1988). Land, traditionally used for agricultural purposes, has over the years been fragmented as a regular phenomenon for various reasons (Shrestha, 2011).

Fragmentation, disparity and irregular shapes of land in the agricultural enterprises lead to time wastage in going to and coming from these parcels, difficulty in machinery use, inability to apply modern agricultural technology, waste of capital and labor, loss of soil and productivity and arising land conflicts. So, the development and modernization of the agricultural enterprises have a very slow pace because of such problems (Cicek, 1996).

Boundaries of parcel are separated by stone walls, ditches etc, which cause land wastages, uncultivated at the margins of the parcels, increase cost of fencing and neighboring conflicts, cannot use modern machine in the tiny parcels and may require manual work (Demetriou, 2014). Land fragmentation is directly associated with six relevant factors 
which are; the land holding size, the number of parcels belonging to the holding, the size of each parcel, the shape of each parcel, the spatial distribution of parcel and the size distribution of the parcel (King \& Burton, 1982).

Land fragmentation is said to harm productivity in a number of ways. First, fragmented land holdings can increase transport costs. If the plots are located far from the home, and far from each other, there is a waste of time for the workers spent on travelling inbetween the plots and the home. Management, supervision and securing of scattered plots can also be more difficult, time consuming, and costly. Small and scattered plots and waste land area require more land for fencing, border constructions, and paths and roads (Rose \& Richard, 2002). Land fragmentation involves a complicated boundary network among parcels (hedges, stone walls, ditches, etc.) which cause land wastage because a part of a holding (especially in small parcels) remains uncultivated at the margins of the parcels (Karouzis, 1977; Burton, 1988). Small fragmented land holdings might also cause difficulties to grow certain crops, and prevent farmers from changing to high profit crops. More profitable crops, like for example fruit crops, require larger plot areas, so if the farmers only poses small and fragmented plots they may be forced to grow only less profitable crops (The World Bank, 2005).

A benefit associated with land fragmentation is the variety of soil and growing conditions that reduce the risk of total crop failure by giving the farmer a variety of soil and growing conditions. Many different plots allow farmers access to land of different qualities when it comes to soil, slope, micro-climatic variations, etc. Fields with high yields one year may degrade the soil and it may generate much lower yields in the following year, thus several plots of the same crop also spreads out the risk. In addition, a holding with several plots facilitates crop rotation and the ability to leave some land fallows (Bentley, 1987). Spatially separated farmland lowers the risk that the entire crop is affected by the disaster and disease in the same growing season (Li, 2010). Land fragmentation enhances the production risk by increasing the product diversity. In the fragmentation situation, the agriculture product diversity may be increased. Because when the households have several plots which differ in micro-climatic and environmental conditions, there is possibility of growing more type of crops or plant a certain (Fenoaltea, 1976; Heston\& Kumar, 1983).

Fragmentation is also a common characteristic of agricultural land in Nepal. People have right to sell and buy private land in any part of Nepal and parcel fragmentation is resulted due to the continuous land transaction. By inheritance provision of equal division of property among sons and recently to daughters also caused fragmentation of land. The structure of the land inheritance system, haphazard housing and urbanization 
planning, and loosely-enforced policies are all responsible for land fragmentation in Nepal (CRSC, 2012). Land fragmentation is rooted in traditional inheritance practices whereby the parental estate is divided equally among sons (Sapkota, 2004). Land fragmented is considered as a major obstacle to agricultural mechanization, causing inefficiencies in production and involves large cost to alleviate its effects in Nepal also (Niroula and Thapa, 2007).

Thus, land fragmentation is identified as one of the problems of agricultural development in Nepal. It is in this context this paper discusses characteristics of land fragmentation, its causes and implication in agricultural development in Nawalparasi district, Nepal.

\section{Approaches and methods}

Based on the review of literature a research framework was designed (Figure 1). Both quantitative and qualitative types of data were collected and processed. The detail information was collected at two levels. Those are at district level and VDC level. The sources of data at district level are secondary whereas primary data was collected for analysis at VDC level.

Firstly, the trend of the number of changes in one of the parcels was assessed; secondly the causes or factors responsible to develop such trend were identified and lastly the consequences of land fragmentation were assessed based on the level of input use and level of production (output).

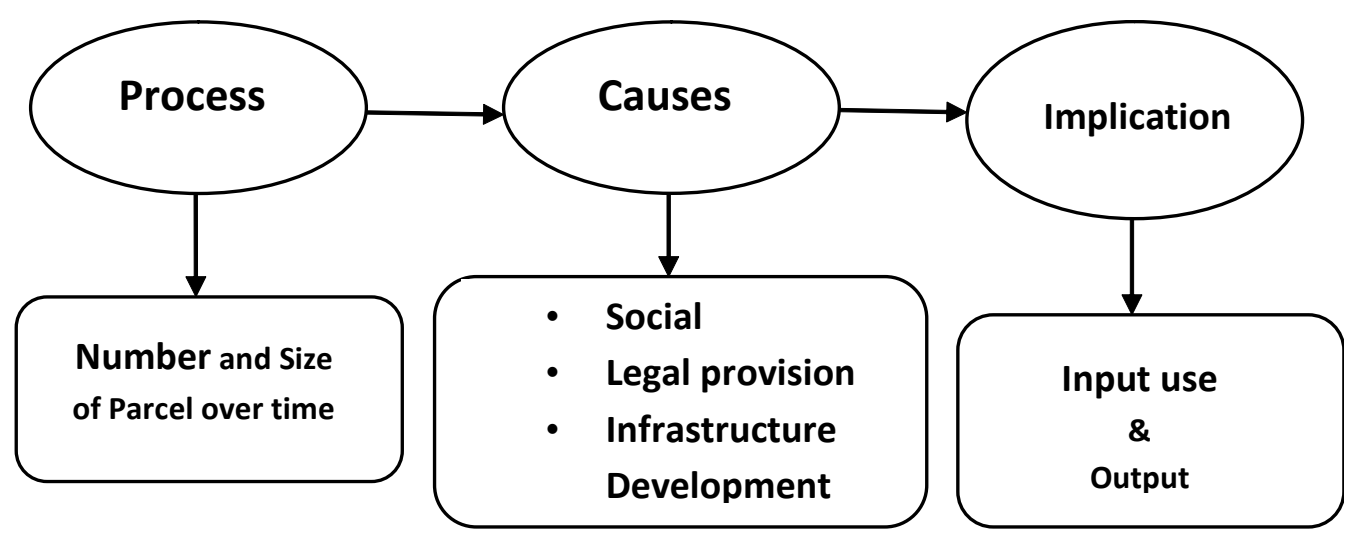

Figure 1: A research framework

Both primary and secondary sources of data were collected. Secondary sources of information were the published reports and unpublished documents from District 
Development Committee, Village Development Committees, Ministry of Agriculture Development and Central Bureau of Statistics, Government of Nepal. Four methods were adopted while collecting primary data at VDC level. Those were i) Household Survey, ii) Focus Group Discussion (FGD), iii) Key Informant Interview (KII) and iv) Field Observation. The use of different methods helped to cover all the aspects associated with agricultural land use on the one hand and evaluate the reliability of the information derived from different types of surveys on the other.

Multi-stage sampling method was adopted. Firstly, three VDCs were selected randomly one VDC from each three major physiographic units in the district. After selecting the VDC, one ward from each VDC was selected randomly for household survey. Some statistical norms were adopted while determining the sample size for this study. As per the Central Limit Theorem when the sample size is large, the mean computed from simple random sample is approximately normally distributed. Furthermore, one rule of thumb states that the large sample size should be 30 or more (Daniel and Terrell, 1995). Keeping in view these statistical norms, a total of 31 households from each ward were taken into consideration for interview. A list of household head within Ward selected for household was obtained from VDC office and this was used as the sample frame for household survey. A random table was consulted while selecting the household for interview in each ward.

A total of seven Focus Group Discussions (FGD) was organized where 9 to 14 people were participated representing from farmers group, senior citizens and school teachers. Similarly Key Informant Interview (KII) was conducted with fifteen personals including Ex-Chairman and members of VDCs and Wards, schools teachers, senior citizens, members of farmer's cooperative and government officials from DADO, Nawalparasi district. The main issue of discussion was on present agriculture condition, production trends, cropping pattern, problems, trends and causes of land fragmentation and the consequences of land fragmentation in agriculture development.

GPS coordinate of surveyed houses were captured during the field survey and location, shape and size of each parcels was obtained through digitization of cadastral maps. The shortest crow fly distance was taken into consideration while calculating the distance from house to different plots and among plots owned by each household. After data collection the inconsistencies were checked and local units were converted into SI unit. The data was entered into computer system using SPSS, MS-Excel and Arc GIS 10.1 software was used to analysis spatial data. 


\section{Study area}

Nawalparasi district lies in the southern part of western development region of Nepal. It is extended between $27^{\circ} 21^{\prime}$ 'north to $27^{\circ} 41^{\prime}$ north latitude and $83^{\circ} 36^{\prime}$ east to $84^{\circ} 35^{\prime}$ east longitude. The altitude ranges from 91 to 1936 meters from the mean sea level. This district is surrounded by Palpa district to the north, Tanahun district to the northeast, Chitwan district to south-east and Rupandehi district to the west. Similarly, the district borders with India to the southern part. The total area of this district is about $2162 \mathrm{~km}^{2}$ (DDC, 2015). Parasi is the district headquarters, located at southern part of the district. There are a total of 101337 agricultural holdings in the district with the area of 56125.2 hectares whereas total number of households in the district is 128793 and total population is 643508 . It gives a population land ratio of 11 persons per hectare and population density is 298 persons per $\mathrm{km}^{2}$ (CBS, 2011).

Nawalparasi district has 56 Village Development Committees (VDCs) and seven Municipalities (Now, there are seven Municipalities and eight Rural Municipalities). Three VDCs namely Ramnagar (Now, in Sunwal Municipality), Palhi (Now, in Palhinandan Rural Municipality) and Jahada (Now, in Bardaghat Municipality) were selected for the study among 56 VDCs of Nawalparasi district.

Ramnagar VDC is situated between Chure hill in northern side and plain land in southern part. The major land unit type in this VDC is very gentle slope where more than 80 $\%$ of land area of ward number 5 is composed of this type of land unit. The wetland cultivation covers about $64 \%$ of the total agricultural area, and the rest by mixed land cultivation (LRMP, 1986). The main food crops are paddy, wheat and maize. Rice is a summer crop while wheat, pulses and oilseeds are winter crops. Vegetable crops such as cauliflower, cabbage, potato, peas, carrot, reddish, chilli and so on are also grown here. Dominant cropping pattern in the wetland cultivation are rice-wheat, and rice-wheat/ oilseeds. Cropping pattern in the mixed land cultivation is mainly characterized by riceoilseeds/pulses and rice-wheat/oilseeds. There is surface irrigation system in this VDC. More than 70 percent area of agricultural land is irrigated by this system. This VDC has good access to road infrastructure and service. No village is located far way from 30 minutes walking distance from road head.

Jahada VDC is located in the middle part of the district which has undulating type of land unit surface and almost all area of the ward number 3 is composed of this type of land unit. All the agricultural land use pattern of the Jahada VDC is categorized as 
Tarai Cultivation based on the physiographic characteristics and Wet Land Cultivation based on the land form and land system. A variety of food crops are grown in this VDC. The major food crops are paddy and wheat. Besides these crops, sugarcane, pulses and oilseeds are also grown in this VDC. Some vegetables also produced in this VDC which are potato, cauliflower, cabbage, tomato, cucumber, garlic, chilly, onion, etc. Though there is not any canal irrigation in this VDC, irrigation is done through boring of underground water. Only 55.0 percent of the total cultivated land has irrigation facility. Of the total irrigated land 23.7 percent of the land has irrigation facility all-round the year whereas about 31.3 percent of land has irrigation facility only in rainy season.This VDC is located at a distance of $13 \mathrm{~km}$ from the district headquarters, Parasi. All the wards are connected by graveled and earthen roads.

Palhi VDC is located in southern part of the district having dominant of depressional type of land unit where more than sixty percent of land area of ward number 9 is composed of this type of land unit. Agricultural land of the Palhi VDC is classified as Tarai cultivation based on the physiographic characteristics. All the agricultural land falls under wetland cultivation category. The wetland is further divided into lowland $k$ ket and upland khet. About $98.28 \%$ of wetland cultivation is of upland khet category and $1.72 \%$ wetland cultivation is of lowland category. The cropping pattern of the VDC varies according to agricultural land types, irrigation and precipitation. The wetland cultivation comprises of crops such as rice, wheat, pulses, mustard, and vegetables. Rice is the dominant summer crop whereas wheat pulses, oilseeds are cultivated in the winter season. Rice-wheat is grown in $75 \%$ area and rice-pulse is grown in $22.5 \%$ of total cultivated land of the VDC and rice-maize, rice-oilseeds and sugarcane, etc. are grown in other areas. In this VDC vegetables and fruits are produced in small quantity, only for household consumption. Major vegetables produced in this VDC are potato, cauliflower, cabbage, tomato, cucumber, bitter gourd, radish, pumpkin etc. Likewise, some spices crops such as turmeric, garlic, chilly, and onion are also produced. Irrigation is done through boring of underground water as the main source of irrigation in this VDC. Of the total cultivated land 73 percent has irrigation facility. Of the total irrigated land 45 percent of land has irrigation facility all-round the year whereas about 28 percent of land has irrigation facility only in rainy season. This VDC is located at a distance of 8 $\mathrm{km}$ from the district headquarters, Parasi. All the wards are connected by graveled and earthen roads. 


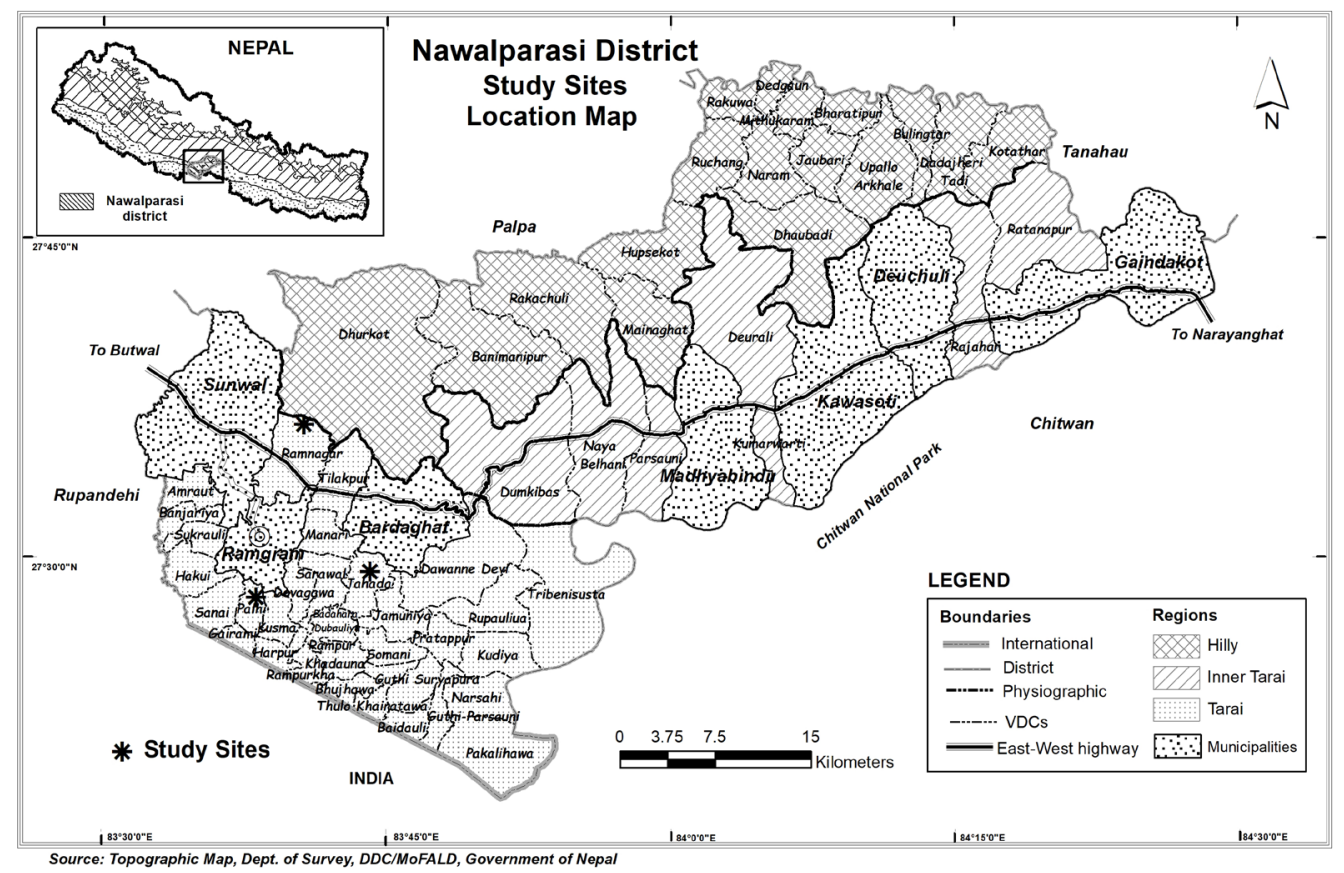

Figure 2: Location map of study area

\section{Result and discussion}

\section{Characteristics of land fragmentation}

There have been changes in the number and size of holdings over time at district level. Number of households with landholding (the holding includes all land operated, whether or not it is owned by the holding). The holding's land may consist of one or more parcels located in one or more separate areas within a district (CBS, 2011). It has increased from $1971 / 72$ to $2011 / 12$ by $459 \%$ (increased from 18144 to 101337 ). It has been consistently increased though the rate of increase differs. At the same time, the size of landholding has decreased from 2.0 ha to 0.55 ha during the same period (Figure 3). Similarly, the total number of parcels has also been increased from 1971/72 to 2011/12 by $60 \%$. Whereas average number of parcel has decreased from 9.4 to 2.7 during the same period in Nawalparasi district (Figure 4). It indicates that large numbers of peoples are depending on small size of land for their subsistence and land patches are increasing (Table 1). 
Bhola Nath Dhakal and Narendra Raj Khanal/ The Geographical Journal of Nepal Vol. 11: 95-112, 2018

Table 1: Number and size of landholding households and parcels in Nawalparasi district

\begin{tabular}{|l|r|r|r|r|r|}
\hline \multicolumn{1}{|c|}{ Particulars } & \multicolumn{1}{|c|}{$\mathbf{1 9 7 1 / 7 2}$} & $\mathbf{1 9 8 1 / 8 2}$ & $\mathbf{1 9 9 1 / 9 2}$ & $\mathbf{2 0 0 1 / 0 2}$ & $\mathbf{2 0 1 1 / 1 2}$ \\
\hline $\begin{array}{l}\text { Total land Holdings } \\
\text { Households (Number) }\end{array}$ & 18,144 & 33,135 & 64,187 & 82,825 & 101,337 \\
\hline $\begin{array}{l}\text { Total landholding } \\
\text { Area (ha.) }\end{array}$ & $36,232.5$ & $47,902.0$ & $71,566.7$ & $58,753.1$ & $56,125.2$ \\
\hline $\begin{array}{l}\text { Average size of Holdings } \\
\text { (ha.) }\end{array}$ & 2.00 & 1.45 & 1.11 & 0.71 & 0.55 \\
\hline Total number of parcels & 171,164 & 180,337 & 182,577 & 201,591 & 274,015 \\
\hline $\begin{array}{l}\text { Average number of parcels/ } \\
\text { households }\end{array}$ & 9.4 & 5.4 & 2.8 & 2.4 & 2.7 \\
\hline
\end{tabular}

Source: CBS, National Sample Census of Agriculture, 2011/12

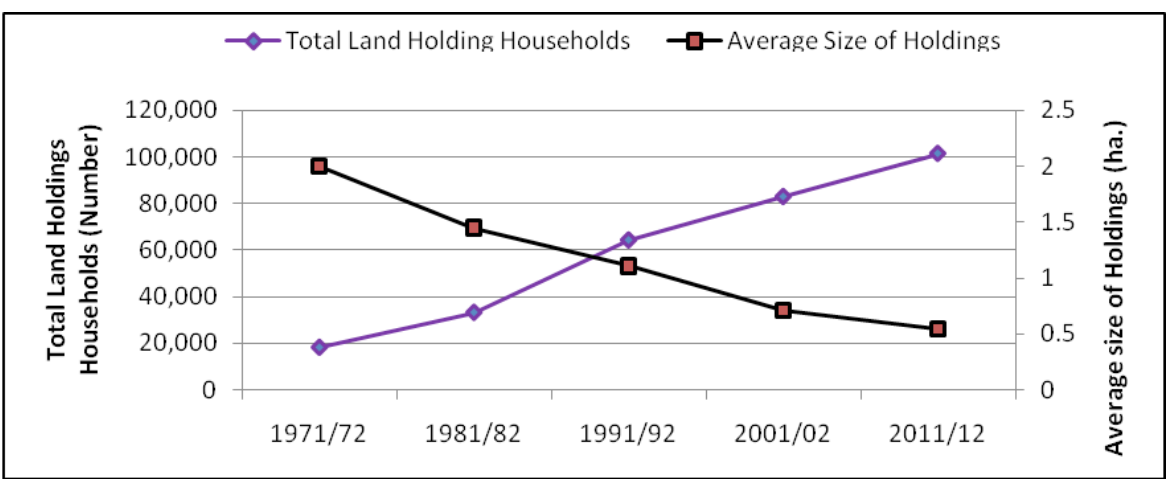

Figure 3: Number of households and size of holding

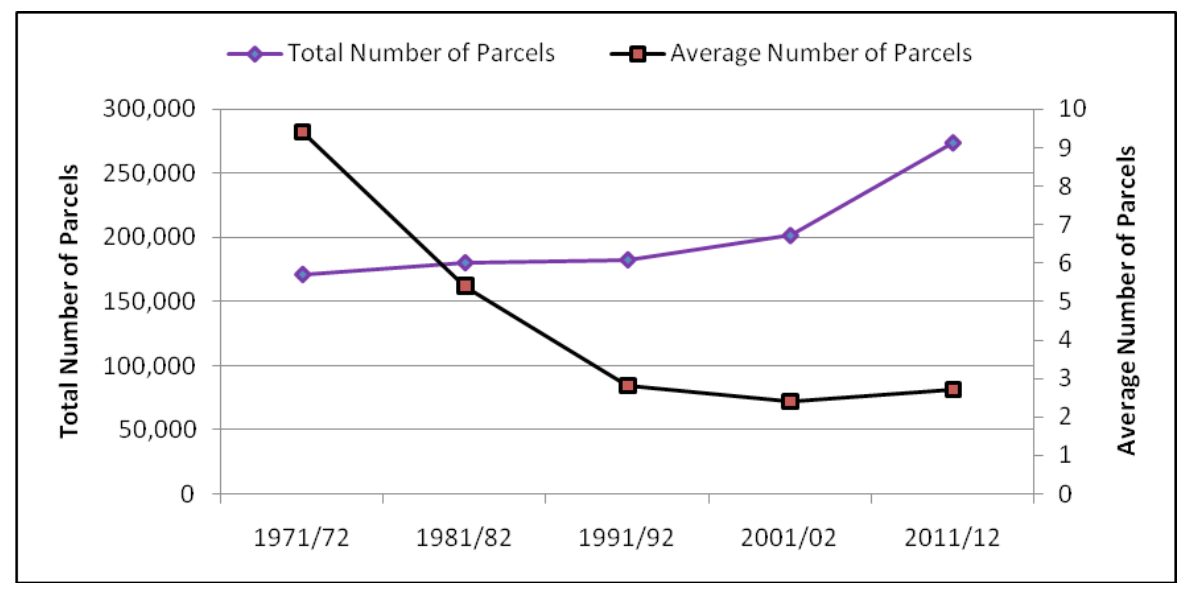

Figure 4: Number and average size of parcels 
From the four census years, it is indicated that $21.1 \%$ of landholdings had single to double number of parcel during 1981/82 which increased to $31.2 \%$ in 2011/12 whereas the percentage of landholdings seems decreasing from 1981/82 to 2011/12 with $47.8 \%$ to $22.4 \%$ having 4 parcels or more. It also reveals that $31.2 \%$ land holding households has one to two numbers of parcels according to census, 2011 whereas $46.4 \%$ households has 3 to 4 number of parcels and $22.4 \%$ land holding households has more than 4 numbers of parcels in Nawalparasi district (Table 2).

Table 2: Number of households and parcels in Nawalparasi district

\begin{tabular}{|c|c|r|r|r|r|}
\hline \multicolumn{2}{|c|}{ Census } & $\mathbf{1 9 8 1 / 8 2}$ & $\mathbf{1 9 9 1 / 9 2}$ & $\mathbf{2 0 0 1 / 0 2}$ & $\mathbf{2 0 1 1 / 1 2}$ \\
\hline \multirow{2}{*}{$\begin{array}{c}\text { Households } \\
\text { with number } \\
\text { of parcels } \\
\text { (in \%) }\end{array}$} & $\mathbf{1 - 2}$ & 21.1 & 26.3 & 31.6 & 31.2 \\
\cline { 2 - 6 } & $\mathbf{3 - 4}$ & 31.0 & 50.9 & 51.0 & 46.4 \\
\hline \multicolumn{2}{|c|}{ Above 4 } & 47.8 & 22.8 & 17.4 & 22.4 \\
\hline \multicolumn{2}{|c|}{ Average size of parcels Area (ha.) } & 0.27 & 0.39 & 0.29 & 0.20 \\
\hline
\end{tabular}

Source: CBS, National Sample Census of Agriculture, 2011/12

\section{Land fragmentation in VDCs}

Nearly 27 percent of the total households surveyed in the three VDCs have less than 2 parcels whereas 53 percent household has 3-4 parcels. The percentage of households having more than 4 parcels is 20 . If we compare these figures with the district and national average, the percentage of household having 3-4 parcels is higher in the study area whereas the percentage of household having more than 4 parcels is less than the district and national level (Table 3 and Figure 5). It indicates that though the land is fragmented in these VDCs, the problem of land fragmentation is not so high as compared to the district and national level.

Table 3: Percentage of households with number of land parcels

\begin{tabular}{|c|r|r|r|}
\hline \multirow{2}{*}{ Number of parcels } & \multicolumn{3}{|c|}{ Households in percentage } \\
\cline { 2 - 4 } & VDC & \multicolumn{1}{|c|}{ District } & \multicolumn{1}{c|}{ National } \\
\hline $1-2$ & 26.7 & 31.2 & 23.6 \\
\hline $3-4$ & 53.3 & 46.4 & 45.0 \\
\hline Above 4 & 20.0 & 22.4 & 31.4 \\
\hline
\end{tabular}

Source: Compiled from Field Survey, 2015/16 and Census, 2011/12 


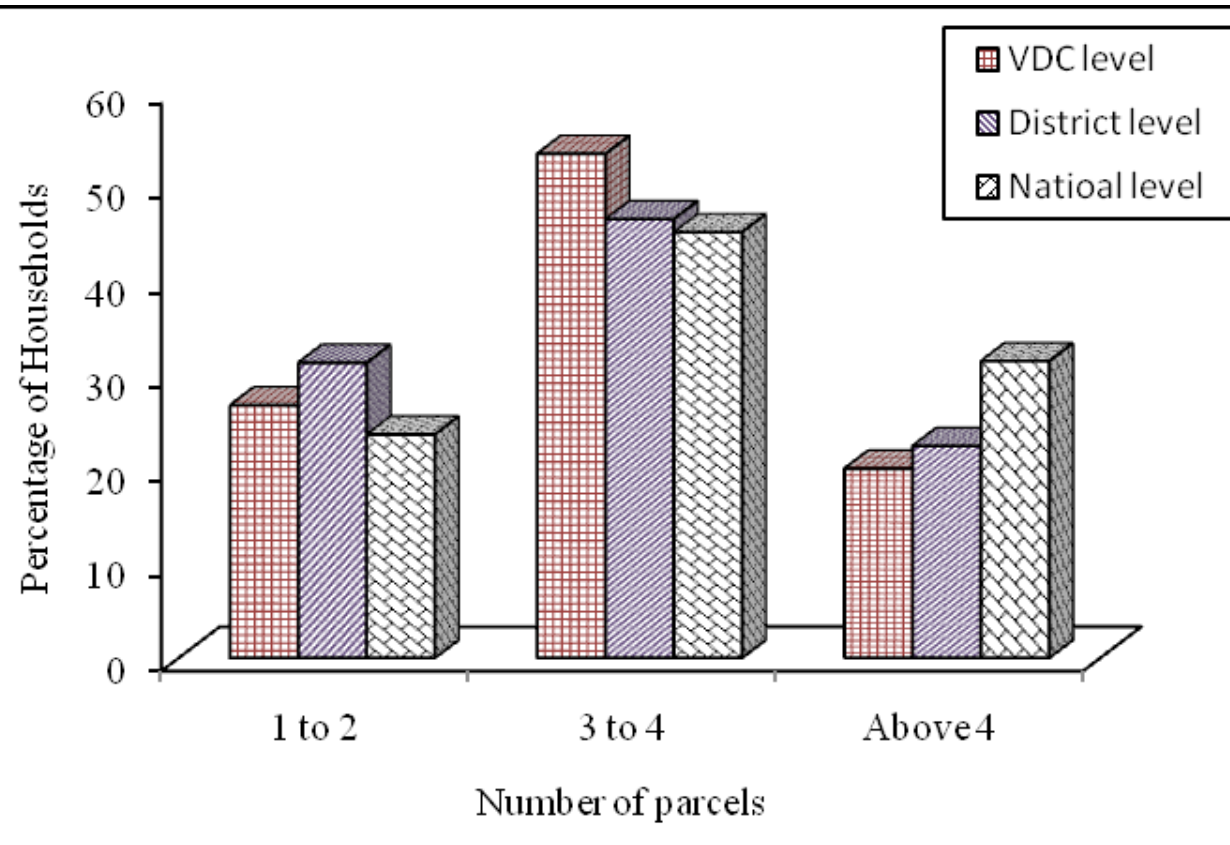

Figure 5: Percentage of households by number of parcels

From the field survey, it is noticed that distance from the house to farm also played the dominant role in agricultural development. There is heterogeneous pattern of distribution of parcels among the households with having different numbers of patches of agricultural land. The average distance from house to plots is more in those households who have 3 to 4 plots as compared to the households having less than 3 or more than 4 plots (Table 4). However, the average distance among all the plots increases with the increase in the number of plots (Table 5).

Table 4: Distance from house to plot (in meters)

\begin{tabular}{|c|r|r|r|r|}
\hline Number of Parcels & $\begin{array}{c}\text { Average size of } \\
\text { parcels (hectare) }\end{array}$ & \multicolumn{1}{|c|}{$\begin{array}{c}\text { Minimum } \\
\text { distance }\end{array}$} & $\begin{array}{c}\text { Maximum } \\
\text { distance }\end{array}$ & $\begin{array}{c}\text { Average } \\
\text { distance }\end{array}$ \\
\hline 2 & 0.6507 & 160 & 1324 & 688 \\
\hline 3 to 4 & 0.4859 & 51 & 3396 & 798 \\
\hline Above 4 & 0.4056 & 25 & 1610 & 636 \\
\hline
\end{tabular}

Source: Compiled from Field Survey, 2015/16 
Table 5: Distance among plots (in meters)

\begin{tabular}{|c|r|r|r|r|}
\hline $\begin{array}{c}\text { Number of } \\
\text { Parcels }\end{array}$ & $\begin{array}{c}\text { Average size of } \\
\text { parcels(hectare) }\end{array}$ & $\begin{array}{c}\text { Minimum } \\
\text { distance }\end{array}$ & $\begin{array}{c}\text { Maximum } \\
\text { distance }\end{array}$ & $\begin{array}{c}\text { Average } \\
\text { distance }\end{array}$ \\
\hline 2 & 0.6507 & 160 & 1324 & 688 \\
\hline 3 to 4 & 0.4859 & 51 & 3396 & 1568 \\
\hline Above 4 & 0.4056 & 0 & 1610 & 3976 \\
\hline
\end{tabular}

\section{Distribution of land parcels: Sample case}

Padam Bahadur Kunwar has four plots of land with the size ranging from 0.057 hectare to 0.169 hectare. The distance from the house to plot number 271 is 119 meters and to plot number 538 is 617 meters (Figure 6).

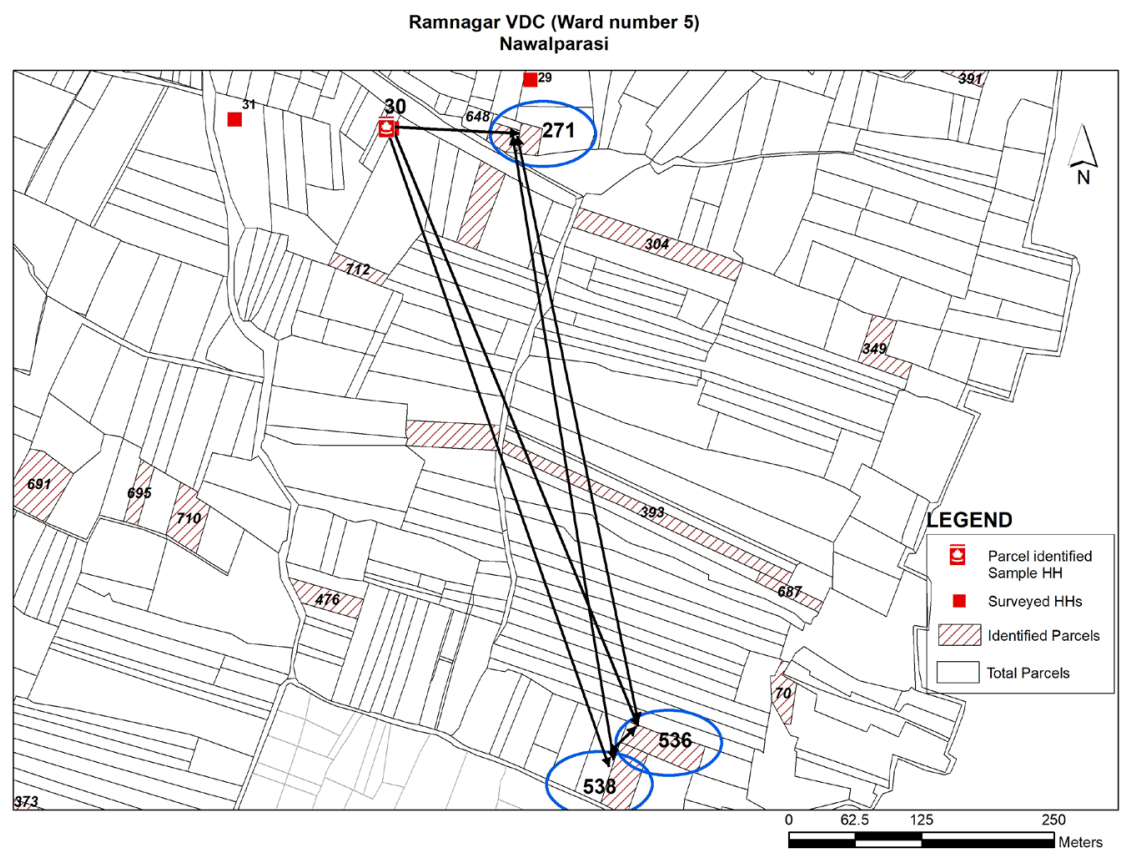

Figure 6: Location of parcels from house

\section{Reasons for land fragmentation}

During Focus Group discussion and KII, it is reported that the rate of land fragmentation in the VDCs has been increasing. High rate of population growth, infrastructure development, and legal provision based on inheritance division and land tenure systemsare responsible for land fragmentation in the study area. Around $90 \%$ respondents 
reported that the in-migration and rapid growth of population is the main reason for land fragmentation (Figure 7). Similarly, $62 \%$ respondents reported that the another reason of land fragmentation is due to infrastructure development, $43 \%$ respondents reported it is due to legal provision of living independently in single family. Further, $38 \%$ respondents informed that land tenure system is also another important reason for land fragmentation in study area. So the land is getting fragmented and people are creating houses and work places differentially.

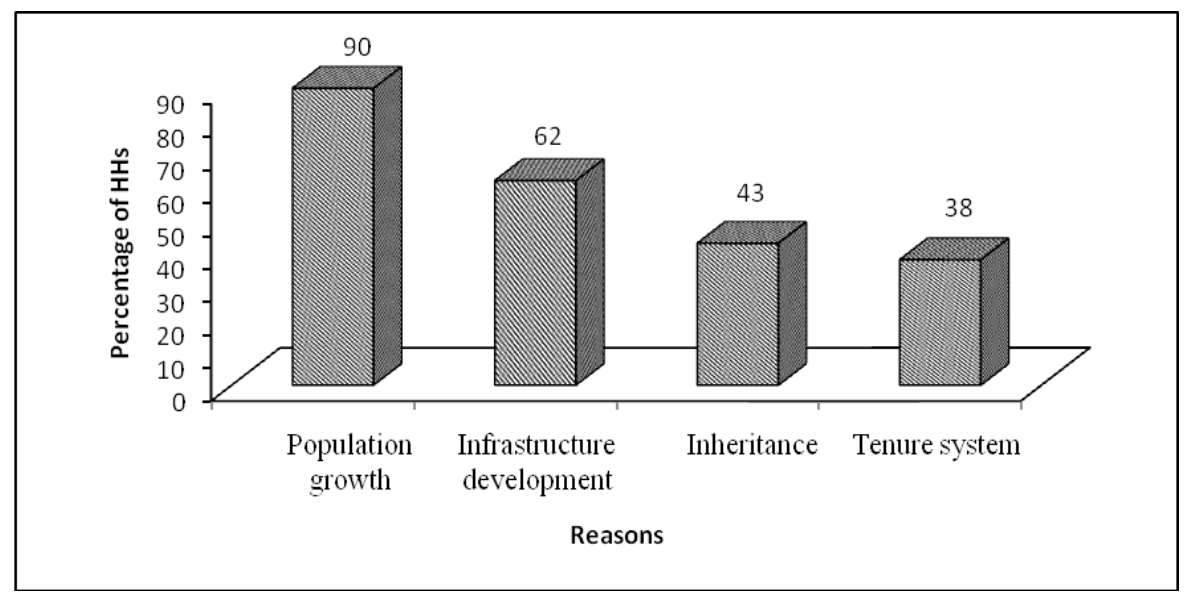

Figure 7: Reasons for land fragmentation

\section{Land fragmentation and consequences}

Land fragmentation has many consequences in agriculture development. Out of 93 households surveyed, large numbers of people (78.5\%) respondents have reported that the fragmentation led to increasing time and cost of input such as labour, fertilizers and pesticides. In the absence of it, productivity has been declining. Similarly $52.7 \%$ of respondents have reported productivity of crops is decreasing due to having increased numbers of small patches of lands and $34.4 \%$ respondents reported that there was the problem of mechanization due to the small size and scattered land patches hence the opportunity of increasing the benefit from agriculture is declining (Table 6). Because of fragmentation, most of the lands are used for plotting and supported for urbanization. This is challenging for the sustainable development of agriculture in future.

However, some respondents also reported that there have some advantages of land degradation in agriculture. They reported that there are possibilities to grow different type of crops in different plots in the same season. It helps them to minimize risk of food insecurity. 
Table 6: Households reporting the consequences of land fragmentation

\begin{tabular}{|l|r|r|}
\hline \multicolumn{1}{|c|}{ Impacts } & $\begin{array}{c}\text { Responding } \\
\text { Households }\end{array}$ & \multicolumn{1}{c|}{$\%$} \\
\hline Increasing use of inputs (labour, fertilizer and pesticides) & 73 & 78.5 \\
\hline Decreasing productivity & 49 & 52.7 \\
\hline Problem for mechanization & 37 & 34.4 \\
\hline Others & 17 & 18.3 \\
\hline
\end{tabular}

Source: Compiled from Field Survey, 2015/16

Variation in input use in agriculture is one of the indicators to measure the consequences of land fragmentation in agriculture. The number of labour use for paddy, potato, oilseeds and pulses cultivation is higher among the households having more than four parcels as compared to the households having single to two and three to four parcels of land for cultivation such higher rate of use of labor is not applicable for wheat. It is mainly due to the use of machine in wheat cultivation than for other crops. On the other hand, it is found that chemical fertilizer (DAP, Potash and Urea) and pesticide inputs increases by different crops for households having high number of parcels than having few numbers of parcels (Table 7).

Table 7: Average input used by types of major crops

\begin{tabular}{|c|c|c|c|c|}
\hline \multicolumn{2}{|c|}{ Number of Parcels } & 1 to 2 & 3 to 4 & Above 4 \\
\hline \multirow{3}{*}{ Paddy } & Labour & 83 & 98 & 102 \\
\hline & Chemical Fertilizer & 196 & 189 & 208 \\
\hline & Pesticides & 94 & 89 & 110 \\
\hline \multirow{2}{*}{ Wheat } & Labour & 61 & 46 & 54 \\
\hline & Chemical Fertilizer & 120 & 214 & 197 \\
\hline \multirow{3}{*}{ Potato } & Labour & 59 & 77 & 83 \\
\hline & Chemical Fertilizer & 237 & 278 & 118 \\
\hline & Pesticides & 73 & 96 & 84 \\
\hline \multirow{2}{*}{ Oilseeds } & Labour & 34 & 54 & 67 \\
\hline & Chemical Fertilizer & 115 & 127 & 118 \\
\hline \multirow{2}{*}{ Pulses } & Labour & 43 & 49 & 55 \\
\hline & Chemical Fertilizer & 75 & 90 & 86 \\
\hline
\end{tabular}

Source: Compiled from Field Survey, 2015/16

Note: labour (person/hectare), chemical fertilizer ( $\mathrm{kg} /$ hectare) and pesticides (ml/hectare) 
Table 8 shows the input and output from agricultural crops in monetary value by the number of parcels owned by the surveyed households. The input in terms of monetary value increases with increasing number of parcels, such higher rate of input use is not applicable for wheat. It is mainly due to the use of machine in wheat cultivation than for other crops. The proportion of net return from output decreases with increasing number of parcels in terms of monetary value in most of the crops. The output is less than input use in pulse cultivation with increasing the number of parcels which results net loss in pulse production. It is mainly due to the use of more labour in pulse cultivation than for other crops.

Table 8:Average input use and output by crops and range of number of parcels (Rs./ha)

\begin{tabular}{|c|l|r|r|r|}
\hline \multicolumn{2}{|c|}{ Number Parcels } & 1 to 2 & 3 to 4 & Above 4 \\
\hline \multirow{4}{*}{ Paddy } & Inputs & 43761 & 50279 & 52641 \\
\cline { 2 - 5 } & Outputs & 170963 & 221972 & 177088 \\
\cline { 2 - 5 } & Net return & 127202 & 171693 & 124447 \\
\hline \multirow{4}{*}{ Wheat } & Inputs & 31433 & 27785 & 30612 \\
\cline { 2 - 5 } & Outputs & 130178 & 112426 & 110454 \\
\cline { 2 - 5 } & Net return & 98745 & 84641 & 79842 \\
\hline \multirow{5}{*}{ Potato } & Inputs & 34311 & 43659 & 41191 \\
\cline { 2 - 5 } & Outputs & 289941 & 138698 & 163314 \\
\cline { 2 - 5 } & Net return & 255630 & 95039 & 122123 \\
\hline \multirow{5}{*}{ Pulseeds } & Inputs & 18901 & 28167 & 33937 \\
\cline { 2 - 5 } & Outputs & 76701 & 77612 & 95562 \\
\cline { 2 - 5 } & Net return & 57800 & 49445 & 61625 \\
\hline & Inputs & 21765 & 25069 & 27511 \\
\cline { 2 - 5 } & Outputs & 28241 & 78238 & 22781 \\
\cline { 2 - 5 } & Net return & 6476 & 53169 & -4730 \\
\hline
\end{tabular}

Source: Compiled from Field Survey, 2015/16

\section{Conclusion}

Study at district and local level shows that large numbers of households have 2 to 3 land parcels. The size of parcels has been decreasing. High rate of population growth, infrastructure development, and legal provision based on inheritance division and land tenure systems are the main reasons for land fragmentation in the study area. Per hectare use of inputs is higher among households having large number of parcels 
as compared to the households having less number of parcels. It is mainly due to the loss of time for travel of labor force since the distance to travel is comparatively higher among households having large number of parcels. The output and the net return from agricultural crops is less among the households having large number of parcels though the opportunity of growing varieties of crops is more among the households having large number of parcels.

\section{References}

Agarwal, S. K. (1972). Economics of land consolidation in India. New Delhi: Chand.

Bentley, J. (1987). Economic and ecological approaches to land fragmentation: In Defense of a Much-Aligned Phenomenon. Annual Review of Anthropology, 16: 31-67.

Burton, S. (1988). Land consolidation in Cyprus: A vital policy for rural econstruction. Land Use Policy, 5(1):131-147.

CBS (2011). Population Census, 2011. Kathmandu: Central Bureau of Statistics (CBS).

CBS (2011). Population monograph of Nepal, 2011/12. Kathmandu: Central Bureau of Statistics (CBS).

CBS (2011). National sample census of agriculture, 2011/12. District Summary (Nawalparasi), Kathmandu: Central Bureau of Statistics (CBS).

CBS (2011). National Sample Census of Agriculture, 2011/12. National Report, Kathmandu: Central Bureau of Statistics (CBS).

Cicek, A. (1996). Socio-economical benefits of the land consolidation and functional analysis of its effect on the crop production value. 2nd Agriculture Economic Congress of Turkey, Cukurova University, Faculty of Agriculture, Department of Agricultural Economy, Adana.

CSRC (2012). Land reform monitoring indicator, Nepal. Kathmandu: Community Self Reliance Center (CSRC).

Daniel, W. W., \& Terrell, J. C. (1995). Business statistics for management and economics. Seventh edition. Briston: Hougton Miffin Company.

DDC (2015). District Profile of Nawalparasi District. Nawalparasi: District Development Committee (DDC). 
Demetriou, D. (2014). The Development of an Integrated Planning and Decision Support System for Land Consolidation. Springer, 20:23-37. DOI 10.1007/978-3-319$02347-2$

Demetriou, D. (2013). A new method for measuring land fragmentation. White Rose Online Journal, 1-32.

Dovring, F., \& Dovring, K. (1960). Land and labor in Europe in 1900-1950. The Hague: Martinus Nyhoff.

FAO (2008). The state of food and agriculture. Rome: Food and Agricultural Organization (FAO) of the United Nations.

Fenoaltea, S. (1976). Risk, transaction costs, and the organization of medieval agriculture.Explorations in Economic History, 13(2):129-151.

Heston, A., \& Kumar, D. (1983). The persistence of land fragmentation in peasant agriculture-an analysis of South Asian cases. Explorations in Economic History, 20(2): 199-220.

Jha, R., Nagarajan, H. K., \& Prasanna, S. (2005). Land fragmentation and its implications for productivity: evidence from Southern India. SAARC Working Paper 2005/01. Australia South Asia Research Centre, RSPAS, Division of Economics, Australian National University.

Karouzis, G. (1977). Land ownership in Cyprus: Past and present. Nicosia: Strabo.

King, R., \& Burton, S. (1982). Land fragmentation: Notes on a fundamental rural spatial problem. Progress in Human Geography, 6(4): 475-494.

Li, Y. (2010). Land fragmentation's larger-scale farming and the input-output efficiency of rice planter. Journal of South China Agricultural University, 10: 72-78.

LRMP, (1986). Land utilization report. Kathmandu: Land Resource Mapping Project, Kenting Earth Science Canada and Department of Topography, Government of Nepal, Kathmandu, Nepal.

McPherson, M. (1982). Land fragmentation: A selected literature review. Development Discussion Paper, 141. Cambridge, MA: Harvard Institute for International Development, Harvard University.

Niroula, G. S., \& Thapa, G. B. (2007). Impact of land fragmentation on input use, crop yield and production efficiency in the mountains of Nepal. Land Degradation and Development, 18: 237-248. 
Niroula, G. S., \& Thapa, G. B. (2005). Impacts and causes of land fragmentation, and lesson learned from land consolidation in South Asia. Land Use Policy, 22(4):358-372.

Rahman, S., \& Rahman, M. (2008).Impact of land fragmentation and resource ownership on productivity and efficiency: The case of rice producers in Bangladesh. Land Use Policy, 26: 95-103.

Rose, M., \& Richard, G. (2002). Land sector analysis; land market, land consolidation, and land re-adjustment component. Uganda: Rural Development Institute, The Government of the Republic of Uganda.

Sapkota, K. (2004). Gender Perspectives on Periurban Agriculture in Nepal. UAMagazine, 2004: 38-39.

Shuhao, T. (2005). Land fragmentation and rice production: A case study of small farms in Jiangam Province, P. R. China, Unpublished PhD Thesis, Wageningen University.

Shrestha, B. (2011). Land development boom in Kathmandu Valley (Commercial Pressure on Land Issues). Kathmandu: CDS and Rome, ILC.

Sundquist, J. L. (1988). Needed: A Political Theory for New Era of Coalition Government in United States. Political Science Quarterly, 103:613-635.

The World Bank (2005). Land consolidation issues in northern vietnam-institutions, implementation, impacts. Working paper. Washington D.C.: The World Bank.

Tan, S., Heerink, N., \& Qu, F. (2006). Land fragmentation and its driving forces in China. Land Use Policy, 23(3): 272-285.

Van, D. T. (2003). Dealing with central european land fragmentation. Delft: Eburon.

Van Hung, P., MacAulay, G., \& Marsh, S. (2007). The economics of land fragmentation in the North Vietnam. The Australian Journal of Agricultural and Resource Economics, 51:195-211.

Wu, Z., Liu, M., \& Davis, J. (2005). Land Consolidation and Productivity in Chinese Household Crop Production. China Economic Review, 16:28-49. 